\title{
A Review of Phosphorus Removal Structures: How to Assess and Compare Their Performance
}

\author{
Chad Penn ${ }^{1, *}$, Isis Chagas ${ }^{2}$, Aleksandar Klimeski ${ }^{3}$ and Gry Lyngsie ${ }^{4}$ \\ 1 USDA Agricultural Research Service, National Soil Erosion Research Laboratory, \\ West Lafayette, IN 47907, USA \\ 2 Department of Agricultural and Biological Engineering, Purdue University, West Lafayette, IN 47907, USA; \\ ichagas@purdue.edu \\ 3 Luonnonvarakeskus (LUKE)—Natural Resources Institute Finland, Planta, 31600 Jokioinen, Finland; \\ aleksandar.klimeski@luke.fi \\ 4 Department of Plant and Environmental Sciences, University of Copenhagen, 1871 Frederiksberg, Denmark; \\ gry.lyngsie@biol.lu.se \\ * Correspondence: chad.penn@ars.usda.gov; Tel.: +1-765-494-0330
}

Received: 29 June 2017; Accepted: 1 August 2017; Published: 10 August 2017

\begin{abstract}
Controlling dissolved phosphorus (P) losses to surface waters is challenging as most conservation practices are only effective at preventing particulate $\mathrm{P}$ losses. As a result, $\mathrm{P}$ removal structures were developed to filter dissolved $\mathrm{P}$ from drainage water before reaching a water body. While many $\mathrm{P}$ removal structures with different $\mathrm{P}$ sorption materials (PSMs) have been constructed over the past two decades, there remains a need to evaluate their performances and compare on a normalized basis. The purpose of this review was to compile performance data of pilot and field-scale P removal structures and present techniques for normalization and comparison. Over 40 studies were normalized by expressing cumulative P removal as a function of cumulative $\mathrm{P}$ loading to the contained PSM. Results were further analyzed as a function of retention time (RT), inflow P concentration, and type of PSM. Structures treating wastewater were generally more efficient than non-point drainage water due to higher RT and inflow P concentrations. For Ca-rich PSMs, including slag, increased RT allowed for greater P removal. Among structures with low RT and inflow $\mathrm{P}$ concentrations common to non-point drainage, Fe-based materials had an overall higher cumulative removal efficiency compared to non-slag and slag materials.
\end{abstract}

Keywords: phosphorus; phosphorus removal structures; water quality; phosphorus sorption materials; phosphorus removal; best management practices; legacy phosphorus; urban stormwater

\section{Purpose and Justification for Phosphorus Removal Structures}

Phosphorus $(\mathrm{P})$ losses to surface waters are considered one of the main culprits in eutrophication [1]. Until the 1990's, it was thought that the use of conservation practices that reduced sediment transport in runoff was sufficient for managing non-point $\mathrm{P}$ losses. Sediment reduction was understood as being synonymous with $\mathrm{P}$ reduction since $\mathrm{P}$ is dominantly bound tightly to soil particles-i.e., particulate $\mathrm{P}$ - and therefore mostly immobile compared to nutrients such as nitrogen. Only a small portion of soil-bound $\mathrm{P}$ is soluble in runoff and drainage water, which is why dissolved $\mathrm{P}$ was historically considered negligible in regard to management practices [2]. However, as soils become more saturated with P (i.e., "legacy $\mathrm{P}^{\prime \prime}$ ), the P solubility increases as well as the risk of those soils to develop into a non-point $P$ source [3]. For high $P$ soils, erosion control will not reduce dissolved $P$ losses, only particulate P loss. Simply put, dissolved $\mathrm{P}$ will be transported in moving water, even if erosion is eliminated. In addition to dissolved P losses from legacy P soils, significant P loads are lost 
directly from recently applied fertilizer, especially surface applied and non-incorporated fertilizer in urban areas; such events are known as "incidental" P loss.

Incidental $\mathrm{P}$ losses are generally prevented by increasing soil-fertilizer contact through incorporation of fertilizer and improving infiltration of runoff water, thereby allowing P-saturated solution to equilibrate and react with the soil. Incidental loss of recently applied $\mathrm{P}$ is more difficult to prevent in urban areas than agricultural settings due to a greater percentage of impervious surfaces and the lack of incorporation of fertilizer. Not only does the elevated runoff dissolved P concentrations greatly contribute to dissolved $P$ loads in urban areas, the appreciable runoff volumes further increase $\mathrm{P}$ loading. We can generally prevent incidental $\mathrm{P}$ losses through four approaches: (i) reducing $\mathrm{P}$ application rates; (ii) applying fertilizer at the proper time; (iii) reducing fertilizer P solubility; and (iv) reducing runoff volumes through increasing infiltration. Regarding timing, avoiding fertilizer application immediately prior to large rainfall events will decrease incidental P losses. Reduction of $P$ fertilizer solubility is easily achieved in agricultural settings through banding, tillage, and application of liquid fertilizers (self-incorporation). However, this is not always feasible in urban settings, and therefore use of a slow-release P fertilizer is warranted. Last, reduction of runoff and sub-surface drainage volumes in agricultural settings can be achieved through practices such as tile drain flow-control structures and vegetated buffer strips [4,5]. These practices are mostly incompatible with urban watersheds, which are usually highly impermeable and with runoff as the predominant source of water. In urban settings, practices such as pervious pavement and concrete, and temporary water retention structures such as stormwater retention basins and bio-retention cells, will serve to reduce runoff water volumes.

As another potential source of dissolved P to surface waters, legacy P losses can be managed by: (i) preventing the source-i.e., high P soils-from developing in the first place; (ii) containing the P on-site; or (iii) decreasing soil P levels. Preventing soils from becoming saturated with P is the easiest and least expensive approach for dealing with non-point dissolved P losses. Prevention of soil $\mathrm{P}$ build-up is one of the goals of agricultural and urban nutrient management $[6,7]$. However, after a soil becomes excessive in $\mathrm{P}$, the only two options for reducing potential dissolved $\mathrm{P}$ losses is to contain the $\mathrm{P}$ on-site through preventing the water from leaving the site, or removing the $\mathrm{P}$. There will be a considerable lag phase before containment and remediation are able to reduce dissolved $P$ concentrations in inland water bodies due to an already existing high $\mathrm{P}$ surplus [8]. Containment of $\mathrm{P}$ through reducing runoff and sub-surface drainage volume was discussed in the previous paragraph. Containment of legacy $\mathrm{P}$ does not implicate a definitive solution of the problem since the source of $\mathrm{P}$ is not eliminated but managed across the affected sites. In fact, after a soil becomes saturated with $\mathrm{P}$, the only remedy that focuses on the root of the problem is to remove the P from the soil.

Decreasing soil $\mathrm{P}$ concentrations is achieved by ceasing all $\mathrm{P}$ applications and continuing to harvest the P-containing biomass from the site, thereby partly eliminating the P source. However, this process of soil $\mathrm{P}$ "draw-down" can require decades. For example, Fiorellino et al. [9] conducted a long term P draw-down study on soils that had initial Mehlich-3 P concentrations ranging from 200 to nearly $400 \mathrm{mg} \mathrm{kg}^{-1}$. The authors ceased $\mathrm{P}$ applications and removed soil $\mathrm{P}$ via grain and forage crop rotations; they estimated 20 to 25 years until soil P levels return to $100 \mathrm{mg} \mathrm{kg}^{-1}$. Considering an urban setting, similar results were demonstrated by Gotcher et al. [10] using crabgrass. In the meantime, dissolved P losses will occur with every flow event. Due to the long-term nature of soil P draw-down and prevalence of "flashy" and appreciable incidental fertilizer P losses-as discussed above-the $P$ removal structure was developed as an immediate strategy to remove dissolved $P$ from drainage water and surface runoff before reaching a water body [11].

\section{How Phosphorus Removal Structures Operate}

A P removal structure is essentially a landscape-scale filter for trapping dissolved $\mathrm{P}$ in drainage water. The structures can take on many styles and forms, but each possesses the following core components [11]: 
1. It contains a sufficient mass of an unconsolidated $\mathrm{P}$ sorption material (PSMs). PSMs are usually industrial by-products or manufactured materials-although some occur naturally-characterized by a capacity to strongly sorb P.

2. The PSM is contained and placed in a hydrologically active area that receives and/or exhibits dissolved $\mathrm{P}$ concentrations greater than $0.2 \mathrm{mg} \mathrm{L}^{-1}$.

3. High dissolved P water is able to flow through the contained PSM at a suitable flow rate.

4. The PSM can be removed and replaced after it is no longer effective at removing $P$ at the minimum desired rate.

The P removal structure can be utilized for treating any dissolved P source: urban, agricultural, golf course, horticultural, and wastewater. In fact, most of the early work conducted on P removal structures was in the context of municipal, domestic, and agricultural wastewater; the structures were often used in conjunction with treatment wetlands (Table 1). Different styles of P removal structures comply with these four characteristics, including surface runoff confined bed filters [12,13], PSM beds for wastewater [14,15], subsurface beds for wetlands [16-18], subsurface tile drain filters [11], enveloped tile drains [19,20], drainage ditch filters [21-23], modular perforated boxes [21], bio-retention cells $[24,25]$ and blind inlets [26].

Regardless of the source of dissolved P-e.g., municipal, residential, agricultural, etc.-and the style of structure, the heart of the P removal structure is the PSM contained within it. Several studies have highlighted and reviewed many different PSMs [27-35]. In general, PSMs can be reduced to two main categories based on P sorption mechanism: iron (Fe)/aluminum ( $\mathrm{Al}$ ) based PSMs that remove $\mathrm{P}$ by ligand exchange reactions, and calcium (Ca)/magnesium $(\mathrm{Mg})$ based PSMs that work by precipitating $\mathrm{Ca}$ and $\mathrm{Mg}$ phosphate minerals. Some PSMs are able to remove $\mathrm{P}$ by both mechanisms. A detailed discussion of different PSMs and their P sorption mechanisms can be found in Stoner et al. [36] and Penn and Bowen [11].

Because of the inherent variability of $P$ removal structures, their efficacy can substantially vary. Different criteria have been used to characterize performance and estimating that efficacy, which frequently impede the direct comparison among P removal structures. With so many influential factors and ways to report $P$ retention, the evaluation of $P$ removal structures is often interpreted in isolated scenarios, and their results are only valid under certain conditions.

The purpose of this paper is to compile the performance of previously constructed $\mathrm{P}$ removal structures, present an approach for proper evaluation of them, and evaluate their performance after normalization of certain influential factors. Previous reviews provided the first critical step by focusing on PSMs, while several also reported percent cumulative P removal of wastewater treatment wetlands [32-35]. However, this paper takes a further step by reviewing and normalizing the actual performance of pilot and field scale P removal structures, which allows for comparing removal efficiency while also encompassing many different styles of structure and P sources.

\section{Designing P Removal Structures}

Techniques for designing and evaluating a P removal structure are presented in detail in Penn and Bowen [11]. Design and evaluation of P removal structures should be conducted from the perspective of dissolved P loads delivered to the water body, rather than edge-of-field P concentration only. Briefly, dissolved $\mathrm{P}$ concentrations in water bodies are dynamic because of in-stream and in-water body processes. Hence, in regard to concentrations, $\mathrm{P}$ within the water body of interest constitutes the end of most importance, which is a function of $\mathrm{P}$ load delivered.

In essence, design inputs can be reduced to three categories: (i) site hydrology and water quality characteristics; (ii) target P removal and lifetime; and (iii) PSM characteristics. The ability of PSMs to sorb P strongly dictates the size of the P removal structure (i.e., mass and volume of PSM). The core of the design process is sizing the structure as a function of the PSM's "P removal design curve", which considers site inputs and target $\mathrm{P}$ removal. The $\mathrm{P}$ removal curve is simply a mathematical description 
of $\mathrm{P}$ removal under flowing conditions for a given $\mathrm{P}$ inflow concentration and retention time (RT), expressed as a function of P loading (i.e., P added per unit mass of PSM). Similarly, the P removal curve can also be used to predict the performance of an existing $P$ removal structure. Note that batch isotherms are not acceptable for designing $P$ removal structures or predicting their performance. This is because batch isotherms: (i) utilize excessive P concentrations; (ii) do not allow for continuous addition of reactants and removal of reaction products; and (iii) normally have long retention times compared to field-scale P removal structures for non-point drainage [11,34,36,37]. 
Table 1. Summary of design, conditions, and phosphorus $(\mathrm{P})$ removal performance for various wastewater and non-point drainage P removal structures. Data are primarily organized based on inflow water type (wastewater vs. non-point drainage), secondary by type of P sorption material (PSM), and tertiary by chronology. DP: dissolved P.

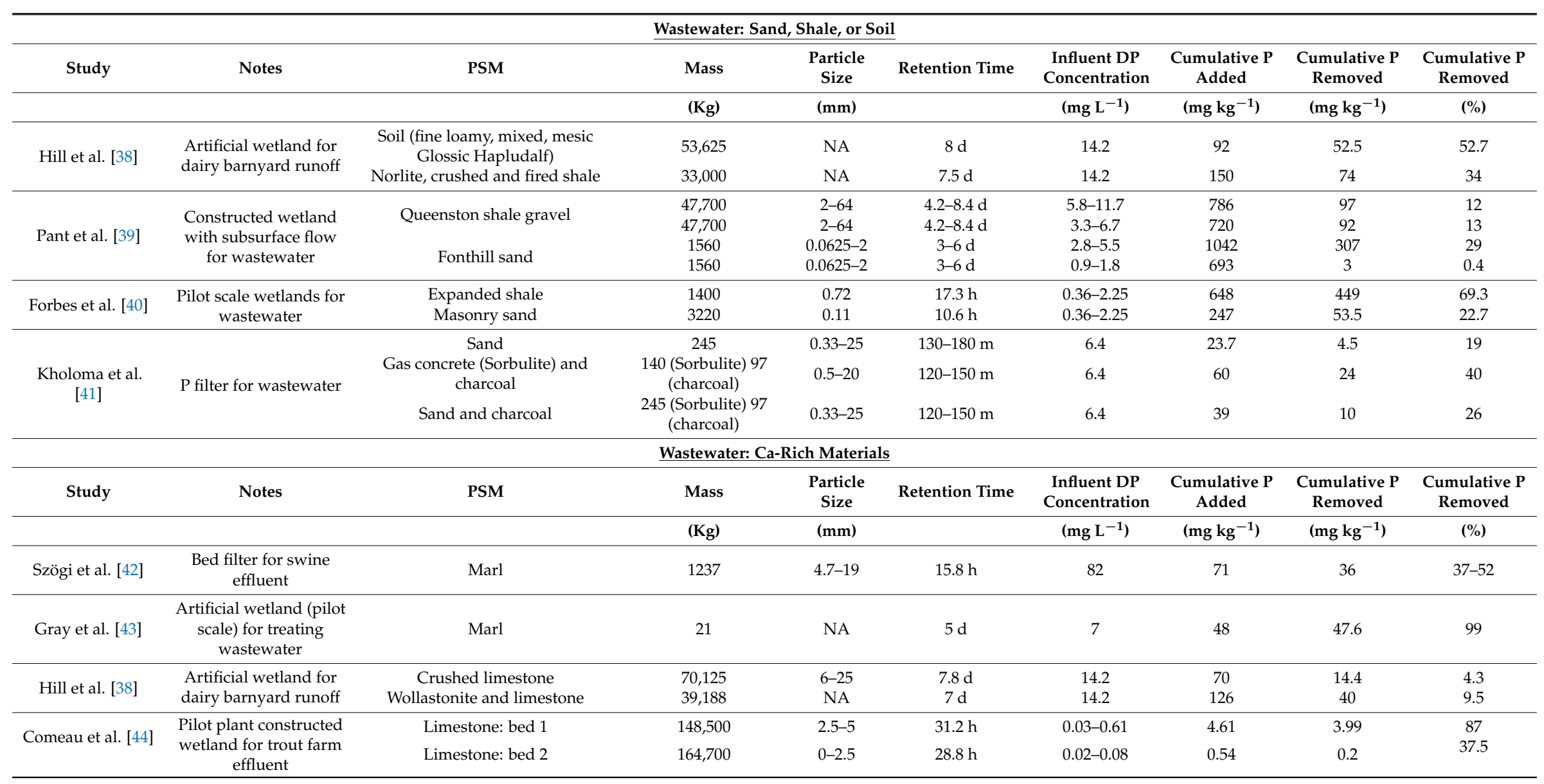


Table 1. Cont.

\begin{tabular}{|c|c|c|c|c|c|c|c|c|c|}
\hline \multicolumn{10}{|c|}{ Wastewater: Ca-Rich Materials } \\
\hline \multirow[t]{2}{*}{ Study } & Notes & PSM & Mass & $\begin{array}{l}\text { Particle } \\
\text { Size }\end{array}$ & Retention Time & $\begin{array}{l}\text { Influent DP } \\
\text { Concentration }\end{array}$ & $\begin{array}{l}\text { Cumulative P } \\
\text { Added }\end{array}$ & $\begin{array}{l}\text { Cumulative P } \\
\text { Removed }\end{array}$ & $\begin{array}{c}\text { Cumulative P } \\
\text { Removed }\end{array}$ \\
\hline & & & $(\mathrm{Kg})$ & $(\mathrm{mm})$ & & $\left(\mathrm{mg} \mathrm{L}^{-1}\right)$ & $\left(\mathrm{mg} \mathrm{kg}^{-1}\right)$ & $\left(\mathrm{mg} \mathrm{kg}^{-1}\right)$ & $(\%)$ \\
\hline Pant et al. [39] & $\begin{array}{l}\text { Constructed wetland } \\
\text { with subsurface flow } \\
\text { for wastewater }\end{array}$ & Lockport dolomite & 45,300 & $0.0625-2$ & $4-8 \mathrm{~d}$ & $1.6-3.2$ & 218 & 35 & 16 \\
\hline Arias et al. [17] & $\begin{array}{l}\text { Constructed wetland } \\
\text { for wastewater }\end{array}$ & Calcite & 189 & $<2$ & $28-99 \mathrm{~m}$ & 7.3 & 13,904 & 3174 & 23 \\
\hline Vohla et al. [45] & $\begin{array}{l}\text { Constructed subsurface } \\
\text { wetland for wastewater }\end{array}$ & $\begin{array}{l}\text { Calcareous sediment from } \\
\text { oil-shale ash plateau }\end{array}$ & 1400 & $0.002-0.125$ & $48 \mathrm{~h}$ & 6.94 & 11,743 & 656 & 5.6 \\
\hline $\begin{array}{c}\text { Søvik and Klove } \\
\text { [46] }\end{array}$ & $\begin{array}{c}\text { Meso-scale filter for } \\
\text { wastewater from single } \\
\text { household }\end{array}$ & Shell sand ("Korall sand") & 666 & $\begin{array}{l}\quad>1 \\
\text { (pre-filter) } \\
<1 \text { (main } \\
\text { filter) }\end{array}$ & $4.4-10.5 \mathrm{~d}$ & 7.8 & 335 & 285 & 85 \\
\hline \multirow{2}{*}{ Ádám et al. [47] } & $\begin{array}{l}\text { Meso-scale wastewater } \\
\text { treatment }\end{array}$ & Filtralite-P & 359 & $0-4$ & $4.3 \mathrm{~d}$ & 6 & 526 & 521 & 99 \\
\hline & $\begin{array}{c}\text { Large-scale wastewater } \\
\text { treatment }\end{array}$ & & 99,000 & $0-4$ & $17.7 \mathrm{~d}$ & 2.9 & 54 & 52 & 97 \\
\hline $\begin{array}{l}\text { Karcmarczyk and } \\
\text { Renman [48] }\end{array}$ & $\begin{array}{l}\text { Subsurface constructed } \\
\text { wetland for wastewater }\end{array}$ & $\begin{array}{l}\text { Sand, Ca addition, scrap iron, } \\
\text { bentonite, bark, straw }\end{array}$ & NA & $0.05-2$ & $8.6 \mathrm{~d}$ & 8 & NA & 373 & $24-96$ \\
\hline Shilton et al. [49] & $\begin{array}{l}\text { Column field test for } \\
\text { wastewater }\end{array}$ & Tararua limestone & 24 & NA & $12 \mathrm{~h}$ & 10 & 1344 & 968 & 72 \\
\hline \multicolumn{10}{|c|}{ Wastewater: Steel Slag } \\
\hline \multirow[t]{2}{*}{ Study } & Notes & PSM & Mass & $\begin{array}{l}\text { Particle } \\
\text { Size }\end{array}$ & Retention Time & $\begin{array}{l}\text { Influent DP } \\
\text { Concentration }\end{array}$ & $\begin{array}{l}\text { Cumulative P } \\
\text { Added }\end{array}$ & $\begin{array}{l}\text { Cumulative P } \\
\text { Removed }\end{array}$ & $\begin{array}{c}\text { Cumulative P } \\
\text { Removed }\end{array}$ \\
\hline & & & $(\mathrm{Kg})$ & $(\mathrm{mm})$ & & $\left(\mathrm{mg} \mathrm{L}^{-1}\right)$ & $\left(\mathrm{mg} \mathrm{kg}^{-1}\right)$ & $\left(\mathrm{mg} \mathrm{kg}^{-1}\right)$ & $(\%)$ \\
\hline Shilton et al. [49] & $\begin{array}{l}\text { Column field test for } \\
\text { wastewater }\end{array}$ & Iron slag & 24 & NA & $12 \mathrm{~h}$ & 10 & 1168 & 210 & 18 \\
\hline Shilton et al. [14] & $\begin{array}{c}\text { Confined bed for } \\
\text { wastewater treatment }\end{array}$ & Steel slag & $17,773,695$ & $10-20$ & $72 \mathrm{~h}$ & $8.4($ total P) & 3400 & 1200 & 35 \\
\hline $\begin{array}{c}\text { Korkusuz, et al. } \\
{[50]}\end{array}$ & $\begin{array}{l}\text { Vertical subsurface flow } \\
\text { wetland for wastewater }\end{array}$ & Blast furnace slag & 9389 & $<3$ & $2.9 \mathrm{~d}$ & 4.6 & 493 & 248 & 50 \\
\hline
\end{tabular}


Table 1. Cont

\begin{tabular}{|c|c|c|c|c|c|c|c|c|c|}
\hline \multicolumn{10}{|c|}{ Wastewater: Steel Slag } \\
\hline \multirow[t]{2}{*}{ Study } & Notes & PSM & Mass & $\begin{array}{c}\text { Particle } \\
\text { Size }\end{array}$ & Retention Time & $\begin{array}{l}\text { Influent DP } \\
\text { Concentration }\end{array}$ & $\begin{array}{l}\text { Cumulative P } \\
\text { Added }\end{array}$ & $\begin{array}{l}\text { Cumulative P } \\
\text { Removed }\end{array}$ & $\begin{array}{l}\text { Cumulative P } \\
\text { Removed }\end{array}$ \\
\hline & & & $(\mathrm{Kg})$ & $(\mathrm{mm})$ & & $\left(\mathrm{mg} \mathrm{L}^{-1}\right)$ & $\left(\mathrm{mg} \mathrm{kg}^{-1}\right)$ & $\left(\mathrm{mg} \mathrm{kg}^{-1}\right)$ & $(\%)$ \\
\hline \multirow{2}{*}{ Weber et al. [18] } & $\begin{array}{l}\text { P filter for wastewater } \\
\text { connected to artificial } \\
\text { wetland }\end{array}$ & Steel slag & 113 & $5-14$ & $12-24 \mathrm{~h}$ & 29 & 2170 & 1700 & 75 \\
\hline & $\begin{array}{l}\text { Stand-alone } P \text { filter for } \\
\text { wastewater }\end{array}$ & & 113 & $5-14$ & $12 \mathrm{~h}$ & 29 & 1900 & 1200 & 72 \\
\hline $\begin{array}{l}\text { Bird and Drizo } \\
\text { [51] }\end{array}$ & $\begin{array}{l}\text { Constructed wetlands } \\
\text { for milk parlor effluent. }\end{array}$ & $\begin{array}{l}\text { EAF steel slag: after two feeding } \\
\text { cycles }\end{array}$ & 829 & $5-20$ & $18 \mathrm{~h}$ & 42.5 & 2100 & 1464 & 70 \\
\hline $\begin{array}{l}\text { Renman and } \\
\text { Renman [52] }\end{array}$ & Wastewater treatment & Polonite (Ca silicate) & 560 & $2-5.6$ & $1-72 \mathrm{~h}$ & 4.9 & 613 & 545 & 89 \\
\hline \multirow{2}{*}{ Barca et al. [53] } & $\begin{array}{l}\text { Subsurface flow filter to } \\
\text { treat wastewater }\end{array}$ & EAF steel slag & 10,800 & $20-40$ & $\begin{array}{l}17.5-23.8 \mathrm{~h} \text { : then } \\
48 \mathrm{~h} \text { after } 9 \mathrm{w}\end{array}$ & 7.8 & 925 & 320 & 37 \\
\hline & $\begin{array}{c}\text { effluent from } \\
\text { constructed wetland }\end{array}$ & BOF steel slag & 9600 & $20-40$ & $\begin{array}{c}19 \mathrm{~h}-25.7 \mathrm{~h} \text { : then } \\
48 \mathrm{~h} \text { after } 9 \mathrm{w}\end{array}$ & 7.8 & 1040 & 610 & 62 \\
\hline \multicolumn{10}{|c|}{ Wastewater: Mine Drainage Residuals (MDR) and Fe-Rich Materials } \\
\hline \multirow[t]{2}{*}{ Study } & Notes & PSM & Mass & $\begin{array}{c}\text { Particle } \\
\text { Size }\end{array}$ & Retention Time & $\begin{array}{l}\text { Influent DP } \\
\text { Concentration }\end{array}$ & $\begin{array}{l}\text { Cumulative P } \\
\text { Added }\end{array}$ & $\begin{array}{l}\text { Cumulative P } \\
\text { Removed }\end{array}$ & $\begin{array}{l}\text { Cumulative P } \\
\text { Removed }\end{array}$ \\
\hline & & & $(\mathrm{Kg})$ & $(\mathrm{mm})$ & & $\left(\mathrm{mg} \mathrm{L}^{-1}\right)$ & $\left(\mathrm{mg} \mathrm{kg}^{-1}\right)$ & $\left(\mathrm{mg} \mathrm{kg}^{-1}\right)$ & $(\%)$ \\
\hline $\begin{array}{l}\text { Wood and } \\
\text { McAtamney [54] }\end{array}$ & $\begin{array}{l}\text { Pilot-scale constructed } \\
\text { wetland for landfill } \\
\text { leachate }\end{array}$ & Laterite & 3000 & $2-3.5$ & $8 \mathrm{~d}$ & 1.46 & 2.45 & 2.28 & 93 \\
\hline \multirow[t]{2}{*}{ Dobbie et al. [15] } & \multirow[t]{2}{*}{$\begin{array}{l}\text { Wastewater treatment } \\
\text { plant }\end{array}$} & MDR (granular) & $\begin{array}{l}\text { Initially } 2100 \text {, then } \\
1075 \text { after substitution } \\
\text { with gravel }\end{array}$ & $0.002-5$ & $\begin{array}{l}26 \mathrm{~m} \text { (theoretical) } \\
12 \mathrm{~m} \text { (measured) }\end{array}$ & 4 & 57,566 & 21,900 & 38 \\
\hline & & MDR (granular) & 505 & $6.4-9.5$ & $16 \mathrm{~m}$ & $3-5$ & 28,374 & 5970 & 21 \\
\hline \multirow{5}{*}{$\begin{array}{l}\text { Sibrell and Kehler } \\
\text { [55] }\end{array}$} & \multirow{5}{*}{$\begin{array}{l}\text { Pilot scale P filter for } \\
\text { trout farm effluent }\end{array}$} & $\begin{array}{l}\text { Toby creek MDR: } 12 \mathrm{~h} \text { resting } \\
\text { period }\end{array}$ & 11.2 & $0.85-6.3$ & $1.95 \mathrm{~m}$ & 0.0315 & 3303 & 1585 & 48 \\
\hline & & $\begin{array}{l}\text { Blue valley MDR: } 12 \text { resting } \\
\text { period }\end{array}$ & 11.2 & $0.85-4$ & $1.93 \mathrm{~m}$ & $0.03-0.26$ & 3188 & 1689-1976 & $53-62$ \\
\hline & & $\begin{array}{l}\text { GFH (manufactured Fe oxide): } \\
12 \mathrm{~h} \text { resting period }\end{array}$ & 11.2 & $0.21-2$ & $1.93 \mathrm{~m}$ & $0.03-0.26$ & 3188 & $1881-2040$ & $59-64$ \\
\hline & & $\begin{array}{l}\text { Blue valley MDR: regenerated } \\
\text { after sorption cycle }\end{array}$ & 11.2 & $0.43-2$ & $1.93 \mathrm{~m}$ & 0.12 & 3283 & 1871 & 57 \\
\hline & & $\begin{array}{l}\text { GFH (manufactured Fe oxide): } \\
\text { regenerated after sorption cycle }\end{array}$ & 12.2 & $0.21-2$ & $1.93 \mathrm{~m}$ & 0.12 & 3283 & 1684 & 52 \\
\hline
\end{tabular}


Table 1. Cont

\begin{tabular}{|c|c|c|c|c|c|c|c|c|c|}
\hline \multicolumn{10}{|c|}{ Non-Point Drainage: Non-Steel Slag Materials } \\
\hline \multirow[t]{2}{*}{ Study } & Notes & PSM & Mass & $\begin{array}{l}\text { Particle } \\
\text { Size }\end{array}$ & Retention Time & $\begin{array}{l}\text { Influent DP } \\
\text { Concentration }\end{array}$ & $\begin{array}{l}\text { Cumulative P } \\
\text { Added }\end{array}$ & $\begin{array}{c}\text { Cumulative P } \\
\text { Removed }\end{array}$ & $\begin{array}{l}\text { Cumulative P } \\
\text { Removed }\end{array}$ \\
\hline & & & $(\mathrm{Kg})$ & $(\mathrm{mm})$ & & $\left(\mathrm{mg} \mathrm{L}^{-1}\right)$ & $\left(\mathrm{mg} \mathrm{kg}^{-1}\right)$ & $\left(\mathrm{mg} \mathrm{kg}^{-1}\right)$ & $(\%)$ \\
\hline Penn et al. [56] & $\begin{array}{c}\text { Confined ditch filter for } \\
\text { agricultural runoff }\end{array}$ & Mine drainage residuals & 200 & $\begin{array}{c}0.35 \\
\text { (mean) }\end{array}$ & $0.7 \mathrm{~m}$ & $6-16$ & 2727 & 2700 & 99 \\
\hline \multirow[b]{2}{*}{ Faucette et al. [57] } & \multirow{2}{*}{$\begin{array}{l}\text { Runoff socks for } \\
\text { treating synthetic } \\
\text { runoff }\end{array}$} & Compost & 7.2 & $0-25$ & $0.87 \mathrm{~s}$ & 0.86 & 33 & 3.15 & 9.5 \\
\hline & & Compost and "natural sorbent" & $\begin{array}{l}7.2 \text { compost, } 0.165 \\
\text { "natural sorbent" }\end{array}$ & $0-25$ & $0.87 \mathrm{~s}$ & 0.86 & 33 & 11.5 & 35 \\
\hline Bryant et al. [58] & $\begin{array}{l}\text { Drainage ditch filter for } \\
\text { agricultural runoff }\end{array}$ & Flue gas desulfurization gypsum & 110,000 & 0.045 & $31 \mathrm{~h}$ & 1.21 & 66 & 23 & 35 \\
\hline \multirow{4}{*}{$\begin{array}{c}\text { Kirkkala et al. } \\
{[23]}\end{array}$} & \multirow{4}{*}{$\begin{array}{l}\text { Filters for treating } \\
\text { agriculture runoff }\end{array}$} & Spent lime and burnt lime & 2022 & $<3$ & $20 \mathrm{~h}$ & 2.6 & 4888 & 3031 & 62 \\
\hline & & Burnt lime & 58,500 & $<3$ & $25 \mathrm{~h}$ & 0.01 & 6 & 3.1 & 52 \\
\hline & & Burnt lime & 43,875 & $<3$ & $85 \mathrm{~h}$ & 0.003 & 7 & 3.22 & 46 \\
\hline & & Mixed lime & 43,875 & $<3$ & $71 \mathrm{~h}$ & 0.009 & 7 & 3.22 & 46 \\
\hline $\begin{array}{c}\text { Groenenberg et al. } \\
\text { [19] }\end{array}$ & $\begin{array}{l}\text { Enveloped tile drain in } \\
\text { agricultural field }\end{array}$ & Fe-coated sand & 9240 & NA & NA & $1.4-3.1$ & $42-93$ & $38-89$ & $90-95$ \\
\hline $\begin{array}{c}\text { Liu and Davis } \\
\text { [24] }\end{array}$ & $\begin{array}{l}\text { Bio-retention cell that } \\
\text { collects runoff from } \\
\text { parking lot }\end{array}$ & Soil $+5 \%$ WTRs & 7059 & NA & NA & 0.07 & 61 & 30.5 & 60 \\
\hline $\begin{array}{c}\text { Klimeski et al. } \\
\text { [22] }\end{array}$ & $\begin{array}{c}\text { Ditch filter for } \\
\text { agricultural runoff }\end{array}$ & Ca-Fe oxide granules (Sachtofer) & 7000 & $3-15$ & $10-3000 \mathrm{~m}$ & $0.05-0.25$ & 220 & 60 & 27 \\
\hline \multirow{3}{*}{ Penn et al. [21] } & \multirow{3}{*}{$\begin{array}{l}\text { Ditch filter for } \\
\text { agricultural runoff }\end{array}$} & \multirow{3}{*}{ Flue gas desulfurization gypsum } & 58,297 & \multirow{3}{*}{0.04} & \multirow{3}{*}{$1-3 \mathrm{~h}$} & 0.5 & 66 & 18 & 27 \\
\hline & & & 46,054 & & & 1.6 & 19 & 7 & 37 \\
\hline & & & 48,969 & & & 1.3 & 148 & 22 & 15 \\
\hline \multicolumn{10}{|c|}{ Non-Point Drainage: Steel Slag } \\
\hline \multirow[t]{2}{*}{ Study } & Notes & PSM & Mass & $\begin{array}{l}\text { Particle } \\
\text { Size }\end{array}$ & Retention Time & $\begin{array}{l}\text { Influent DP } \\
\text { Concentration }\end{array}$ & $\begin{array}{l}\text { Cumulative P } \\
\text { Added }\end{array}$ & $\begin{array}{l}\text { Cumulative P } \\
\text { Removed }\end{array}$ & $\begin{array}{l}\text { Cumulative P } \\
\text { Removed }\end{array}$ \\
\hline & & & $(\mathrm{Kg})$ & $(\mathrm{mm})$ & & $\left(\mathrm{mg} \mathrm{L}^{-1}\right)$ & $\left(\mathrm{mg} \mathrm{kg}^{-1}\right)$ & $\left(\mathrm{mg} \mathrm{kg}^{-1}\right)$ & $(\%)$ \\
\hline $\begin{array}{l}\text { McDowell et al. } \\
\text { [59] }\end{array}$ & $\begin{array}{c}\text { Filter "socks" placed in } \\
\text { a stream bed }\end{array}$ & Steel slag & 1916 & $2-5$ & $1.34 \mathrm{~m}$ & 0.024 & 3311 & 1456 & 44 \\
\hline \multirow{2}{*}{$\begin{array}{l}\text { McDowell et al. } \\
{[20]}\end{array}$} & \multirow{2}{*}{$\begin{array}{l}\text { Enveloped tile drain } \\
\text { and filter socks in } \\
\text { agricultural field }\end{array}$} & \multirow{2}{*}{$\begin{array}{c}\text { Melter slag (no socks) } \\
\text { Melter slag, with } 10 \text { kg socks per } \\
\text { drain }\end{array}$} & 72,000 & NA & NA & 0.33 & 60 & 36 & 60 \\
\hline & & & 72,120 & NA & NA & 0.33 & 60 & 41 & 69 \\
\hline
\end{tabular}


Table 1. Cont.

\begin{tabular}{|c|c|c|c|c|c|c|c|c|c|}
\hline \multicolumn{10}{|c|}{ Non-Point Drainage: Steel Slag } \\
\hline \multirow[t]{2}{*}{ Study } & \multirow[t]{2}{*}{ Notes } & \multirow[t]{2}{*}{ PSM } & \multirow[t]{2}{*}{ Mass } & \multirow{2}{*}{$\begin{array}{c}\begin{array}{c}\text { Particle } \\
\text { Size }\end{array} \\
(\mathrm{mm}) \\
\end{array}$} & \multirow[t]{2}{*}{ Retention Time } & \multirow{2}{*}{$\begin{array}{c}\begin{array}{c}\text { Influent DP } \\
\text { Concentration }\end{array} \\
\left(\mathrm{mg} \mathrm{L}^{-1}\right) \\
\end{array}$} & \multirow{2}{*}{$\begin{array}{c}\begin{array}{c}\text { Cumulative } P \\
\text { Added }\end{array} \\
\left(\mathrm{mg} \mathrm{kg}^{-1}\right)\end{array}$} & \multirow{2}{*}{$\begin{array}{c}\begin{array}{c}\text { Cumulative P } \\
\text { Removed }\end{array} \\
\left(\mathrm{mg} \mathrm{kg}^{-1}\right)\end{array}$} & \multirow{2}{*}{$\begin{array}{c}\begin{array}{c}\text { Cumulative I } \\
\text { Removed }\end{array} \\
(\%) \\
\end{array}$} \\
\hline & & & & & & & & & \\
\hline $\begin{array}{l}\text { Agrawal et al. } \\
\text { [60] }\end{array}$ & $\begin{array}{l}\text { Filter cartridges for } \\
\text { subsurface drains on } \\
\text { golf course }\end{array}$ & $\begin{array}{l}\text { Activated carbon, cement kiln } \\
\text { dust (CKD) with 95\% sand, steel } \\
\text { slag, and zeolites }\end{array}$ & $\begin{array}{c}14.7 \text { slag, } 7.8 \text { zeolite, } \\
5 \text { activated carbon, } \\
\text { and } 16.8 \mathrm{CKD} / \text { sand } \\
\text { mixture }\end{array}$ & NA & $\begin{array}{l}\text { Median } 3.4 \mathrm{~m} \\
\text { (day 1) and } 2.7 \mathrm{~m} \\
\text { (day 2) }\end{array}$ & $0-1$ & 69 & -101 & -150 \\
\hline \multirow{2}{*}{$\begin{array}{c}\text { Penn and } \\
\text { McGrath [37] }\end{array}$} & \multirow{2}{*}{$\begin{array}{l}\text { Confined bed filter for } \\
\text { treating pond water }\end{array}$} & EAF slag & 454 & $6.3-14$ & $10 \mathrm{~m}$ & 0.38 & 172 & 59 & 34 \\
\hline & & Treated EAF slag & 454 & $6.3-14$ & $10 \mathrm{~m}$ & 0.34 & 149 & 54 & 36 \\
\hline \multirow{3}{*}{$\begin{array}{l}\text { Penn and Bowen } \\
\text { [11] }\end{array}$} & \multirow{3}{*}{$\begin{array}{l}\text { Confined bed filter for } \\
\text { treating pond water }\end{array}$} & EAF slag & 285 & $6.3-14$ & $7 \mathrm{~m}$ & $0.26-0.62$ & 376 & 83 & 22 \\
\hline & & Treated EAF slag: first coating & 285 & $6.3-14$ & $7 \mathrm{~m}$ & $0.16-0.62$ & 233 & 82 & 35 \\
\hline & & Treated EAF slag: second coating & 285 & $6.3-14$ & $7 \mathrm{~m}$ & $0.18-0.41$ & 285 & 80 & 28 \\
\hline Penn et al. [12] & $\begin{array}{l}\text { Confined surface bed } \\
\text { for golf course runoff }\end{array}$ & EAF slag & 2721 & $6.3-14$ & $9 \mathrm{~m}$ & $0.3-1.6$ & 103 & 26 & 25 \\
\hline Penn et al. [13] & $\begin{array}{l}\text { Confined surface bed } \\
\text { for golf course runoff }\end{array}$ & EAF slag & 2721 & $0.5-14$ & $10 \mathrm{~m}$ & 0.5 & 160 & 53 & 33 \\
\hline Wang et al. [61] & $\begin{array}{l}\text { Runoff interception } \\
\text { trenches }\end{array}$ & EAF slag & 6048 & $6.3-14$ & $1 \mathrm{~m}$ & 4.3 & 44 & 8 & 18 \\
\hline Penn et al. [13] & $\begin{array}{l}\text { Confined surface bed } \\
\text { for poultry farm runoff }\end{array}$ & Treated EAF slag & 36,000 & $6.3-14$ & $16.8 \mathrm{~m}$ & $0.5-15$ & 560 & 116 & 21 \\
\hline \multirow{3}{*}{ Penn et al. [21] } & $\begin{array}{l}\text { Modular boxes for } \\
\text { treating pond water } \\
\text { from poultry farm } \\
\text { runoff }\end{array}$ & EAF slag & 15,000 & $6.3-14$ & NA & 1.04 & 37 & 10 & 27 \\
\hline & \multirow{2}{*}{$\begin{array}{l}\text { Ditch filter for } \\
\text { agricultural runoff }\end{array}$} & \multirow{2}{*}{ EAF slag } & 79,495 & \multirow{2}{*}{$6.3-14$} & \multirow{2}{*}{$20 \mathrm{~m}$} & 0.6 & 43 & 11 & 26 \\
\hline & & & $\begin{array}{l}62,801 \\
66,776\end{array}$ & & & $\begin{array}{l}1.5 \\
0.9\end{array}$ & $\begin{array}{c}73 \\
107\end{array}$ & $\begin{array}{c}8 \\
26\end{array}$ & $\begin{array}{l}11 \\
24\end{array}$ \\
\hline
\end{tabular}


An example of $P$ removal curve is shown in Figure 1. The curve is initially produced by plotting the cumulative $P$ loading against the discrete $P$ removal, expressed as a percentage. An exponential regression or some other type of model is then used to fit the data [21,36]. The discrete P removal curve in Figure 1a can be used to predict the total longevity of the material; that is, the x-intercept represents the cumulative P loading to the PSM in which P will no longer be removed from a flowing solution. Next, the discrete P removal curve is integrated in order to produce the cumulative P removal curve (see Penn et al. [21] for equations), expressed as a percentage or a mass of $P$ removed per mass of PSM (Figure 1b,c, respectively). The cumulative P removal curve, along with knowledge of annual $\mathrm{P}$ loading at the site and target $\mathrm{P}$ removal, are used to estimate the mass of the PSM required to meet the P removal goal. For example, $24 \mathrm{Mg}$ of the PSM shown in Figure 1 would be required for a target $\mathrm{P}$ removal of $30 \%$ of the three-year dissolved P load, considering an annual $\mathrm{P}$ loading of $10 \mathrm{~kg}$ through a flow-weighted inflow $\mathrm{P}$ concentration of $1 \mathrm{mg} \mathrm{P} \mathrm{L}^{-1}$. This setup would result in $9 \mathrm{~kg}$ of $\mathrm{P}$ being removed during the evaluated period. Notice that it would be erroneous to make this calculation using the $0.5 \mathrm{mg} \mathrm{P} \mathrm{L}^{-1}$ curve in Figure 1 since the design calculation using P removal curves can only be applied to the conditions under which the P removal curve was produced.
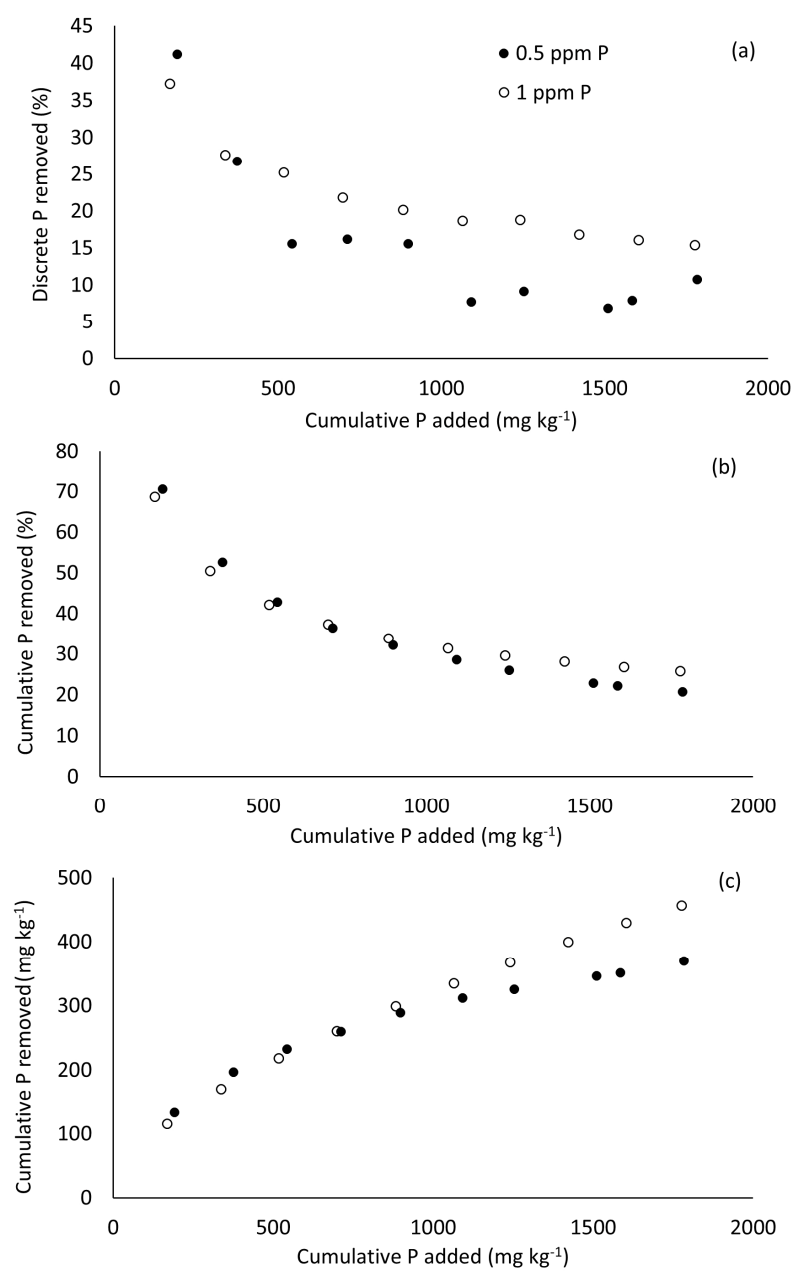

Figure 1. Examples of: (a) discrete $P$ removal curve; (b) cumulative P removal curve expressed as a percentage; and (c) cumulative $\mathrm{P}$ removal curve expressed as $\mathrm{mg} \mathrm{P}$ removed $\mathrm{kg}^{-1} \mathrm{P}$ sorption material (PSM). Flow-through experiment conducted at a retention time of $16 \mathrm{~s}$ with inflow dissolved $\mathrm{P}$ concentrations of 0.5 and $1 \mathrm{mg} \mathrm{L}^{-1}$. The PSM in this example is a Fe-rich mine drainage residual (MDR). 


\section{Evaluation of PSMs and P Removal Structures}

\subsection{Influence of Inflow P Concentration and Retention Time}

In addition to its fundamental role in designing P removal structures, the P removal curve is also a necessary tool for evaluating PSMs and P removal structures. Not only will the P removal curve vary with PSM, but it will also shift as a function of inflow dissolved P concentration (Figure 1) and RT $[36,62]$. The greater efficiency in P removal with increasing inflow $\mathrm{P}$ concentration as shown in Figure 1 is typical. In fact, this variation in efficiency is a function of thermodynamics of the reactions; higher P concentrations translate to higher concentrations of reactants and greater chemical potential for ligand exchange and precipitation reactions to occur. For this reason, $\mathrm{P}$ removal is generally more efficient on a mass basis for $P$ sources such as wastewater than for non-point drainage water, which is much more dilute in P. Inflow dissolved P concentration is therefore an important factor in comparing different PSMs and performance of P removal structures. However, its influence over P removal will vary among PSMs.

Retention time (RT) can also shift the P removal curve for a given PSM, and the magnitude of that shift will likewise vary among PSMs. For PSMs that are sensitive to RT, an increase in RT will generally increase P removal. However, Fe/Al-based PSMs are less sensitive to RT compared to Ca/Mg-based PSMs. This difference is due to the fact that $\mathrm{Ca}$ and $\mathrm{Mg}$ phosphate precipitation is usually slower than ligand exchange of $\mathrm{P}$ onto $\mathrm{Fe}$ and $\mathrm{Al}$ oxides/hydroxides [36,62,63]. An important exception is $\mathrm{Ca} / \mathrm{Mg}$-based PSMs that: (i) possess a high $\mathrm{pH}$ (above 8); (ii) are well buffered with regard to $\mathrm{pH}$; and (iii) produce readily soluble $\mathrm{Ca}$ or $\mathrm{Mg}$. Such $\mathrm{Ca} / \mathrm{Mg}$ PSMs are less sensitive to RT since they are able to precipitate P quickly. Stoner et al. [36] showed that PSMs such as fly-ash were generally insensitive to RT compared to gypsum, which is an excellent soluble Ca source but poorly pH buffered.

\subsection{Normalizing P Removal}

The P removal curve must be expressed as a function of $\mathrm{P}$ addition per unit mass of PSM, as shown in Figure 1. Without this normalization for cumulative P loading, it is rather difficult to evaluate a P removal structure or PSM, or make comparisons among studies. In essence, any reporting of $\mathrm{P}$ removal performance is meaningless without the accompanying cumulative P load to the PSM contained in the structure, expressed as a mass of P per unit mass of PSM. This will be discussed in detail below. Still, even with this foundation of normalization, it is difficult to compare performance of $P$ removal structures and PSMs due to the variability of inflow P concentrations and RT.

Reporting solely the cumulative or discrete removal for the performance of a P removal structure or PSM has been a common practice among scientists and private industry alike. The problem with this approach is that it provides little information on the effectiveness of the unit or the PSM. Without knowing what the corresponding cumulative input $\mathrm{P}$ loading is, a stated percent $\mathrm{P}$ removal will only indicate performance at an unknown loading point. Hence, this value can be deceiving when comparing different structures, considering that $\mathrm{P}$ removal is often near $100 \%$ at initial $\mathrm{P}$ loading of any PSM. For instance, a report of $95 \%$ cumulative $P$ removal may have occurred at a small loading of $3 \mathrm{mg} \mathrm{P} \mathrm{kg}^{-1} \mathrm{PSM}$, as opposed a much greater P loading; unless the corresponding $\mathrm{P}$ loading is specified, the reader cannot properly assess the $P$ removal. Consider how much more effective a PSM would be if it achieved $95 \%$ cumulative removal with a cumulative input $P$ loading of $500 \mathrm{mg} \mathrm{P} \mathrm{kg}-1$ PSM, compared to if this $95 \%$ removal was achieved with only a corresponding input $\mathrm{P}$ loading of $3 \mathrm{mg} \mathrm{kg}^{-1}$.

Lack of knowledge of the accompanied P loading is not only a problem for comparing performance of different structures and PSMs, but it provides no useful information for designing a structure, specifically for estimating the mass of the PSM required to meet a desired P removal goal. Consider for example a hypothetical site with the following characteristics: (i) annual cumulative P loss of $10 \mathrm{~kg}$; (ii) P removal goal of $95 \%$ of the one-year load; and (iii) applicable inflow P concentrations and RT (i.e., same site conditions as defined for the $\mathrm{P}$ removal curve). Two different $\mathrm{P}$ loadings to different PSMs: 
$3 \mathrm{mg} \mathrm{P} \mathrm{kg}-1$ and $500 \mathrm{mg} \mathrm{P} \mathrm{kg}^{-1}$, produce two different scenarios, both reporting cumulative removal of $95 \%$. For the PSM with $95 \%$ removal at $3 \mathrm{mg} \mathrm{P} \mathrm{kg}^{-1}$ loading, about $3333 \mathrm{Mg}$ of that PSM would be required for the structure to meet the P removal goal. For the second scenario with the other PSM and inflow loading of $500 \mathrm{mg} \mathrm{P} \mathrm{kg}^{-1}$, only $20 \mathrm{Mg}$ of the PSM would be necessary to achieve the same cumulative P removal goal of $95 \%$.

Although the input $\mathrm{P}$ loading that accompanies statements of $\mathrm{P}$ removal is frequently not indicated in reports and publications, this information can often be calculated through gleaning of other variables. First, the mass of the PSM must be known to calculate the P loading per unit mass of PSM. If not directly reported, the mass can often be calculated through reports of volume and density of the PSMs utilized. Second, the cumulative mass of P added to the PSM can be estimated by taking into account average (preferably flow-weighted) inflow dissolved $\mathrm{P}$ concentration, input flow rate, and the time elapsed. Knowing the total mass of PSM and input P, the P loading per unit mass is easily calculated.

Even with P removal normalized for P loading to the PSM, making relevant comparisons between PSMs and structures is further complicated because of other influential factors, namely, inflow P concentration and RT. If inflow $\mathrm{P}$ concentration is not reported, it can be calculated from using the following parameters: P loading per unit mass of PSM, mass of PSM, and total inflow volume, which can be determined from the input flow rate and time elapsed. Retention time is calculated as the total pore volume divided by flow rate. If total pore volume is not reported, it can be estimated through total PSM mass or volume, bulk density (if volume is not given), and porosity. Assumptions may be used for bulk density and porosity if they are not reported. Penn and Bowen [11] provide a range of values for PSM physical characteristics.

For this review, all of these techniques were utilized in compiling the summary information shown in Table 1. While many pilot and field-scale studies are included in this review, others were not included because they did not provide all of the necessary information for calculating cumulative $P$ removal and the associated cumulative input loading.

\section{Performance of Previously Constructed P Removal Structures}

Table 1 presents a summary of $\mathrm{P}$ removal performance and conditions for several different $P$ removal structures. The table was organized primarily based on the inflow water type: wastewater vs. non-point drainage. This separation often reflects the degree of inflow dissolved P concentrations, which can have a dramatic impact on P removal. Another useful consequence of separating wastewater is that it also tends to reflect the RT, as the field and pilot scale structures for wastewater typically utilize longer retention times when compared to non-point drainage P removal structures. The wastewater treatment structures often had RTs in the range of hours to days, while non-point drainage water mostly operated with RTs of seconds to hours. The secondary variable for table organization was PSM type, which obviously has a major impact on P removal performance. Shale, sand, and soil were all placed in the same category due to having the least expected P sorption affinity and capacity. Calcium-based PSMs were placed together due to a consistency in P removal mechanism: Ca-phosphate precipitation. Similarly, Fe- and Al-based PSMs were grouped together. One exception in the group of Ca-based PSMs was steel slag. Steel slag is generally a Ca-based material (evidenced by high soluble Ca content, high $\mathrm{pH}$, and $\mathrm{pH}$ buffer capacity), but due to the large body of work conducted on this material in $\mathrm{P}$ removal structures, it was given its own category. Most of the steel slag structures reviewed in this paper are electric arc furnace slag and blast furnace slag, and only a few studies utilized melter slag. The last variable for organization of Table 1, after PSM type, was simply chronology.

Mass of PSMs was indicated in Table 1 in order to convey the relative size of the P removal structures. In addition, particle size was included for two reasons. First, particle size indirectly provides information about the potential for that media to conduct water through it, which is necessary for any $P$ removal structure. Second, particle size is inversely related to surface area, and therefore reactivity.

A brief examination of Table 1 will quickly reveal the diversity in cumulative percent $P$ removal. However, as previously discussed, this value is useless without the associated input P loading. For 
example, in the artificial wetland constructed with Norlite [38], the cumulative percent $\mathrm{P}$ removal might appear superior to that of Pant et al. [39] with $34 \%$ versus $12 \%$ removal, respectively. However, notice that the input P loading to the Norlite with $34 \%$ removal was only $150 \mathrm{mg} \mathrm{kg}^{-1}$ compared to $786 \mathrm{mg} \mathrm{kg}^{-1}$ for the shale gravel used in the Pant et al. [39] study. Keep in mind that for a given material, the cumulative percent $P$ removed will decrease with increased loading (Figure 1b).

Consider now the calcareous oil-shale ash used by Vohla et al. [45] versus the P removal structure utilizing laterite [54]. The former removed only $5.6 \%$ of $\mathrm{P}$ after a loading of nearly $12,000 \mathrm{mg} \mathrm{kg}^{-1}$ dissolved $P$. This translated to a cumulative $P$ removal of $656 \mathrm{mg} \mathrm{kg}^{-1}$, which is a relatively large mass of P removal. On the opposite end, Wood and McAtamney [54] reported a cumulative removal of $93 \%$, but only $2.45 \mathrm{mg} \mathrm{P} \mathrm{kg}^{-1}$ flowed into the structure. To further illustrate how the value of cumulative percent $P$ removed is a somewhat incomplete and misleading statistic when presented alone, notice the lack of relationship between cumulative $\mathrm{P}$ added and percent cumulative $\mathrm{P}$ removed shown in Figure 2a for all of the data listed in Table 1. This lack of relationship also highlights the great diversity in $\mathrm{P}$ removal potential between different materials.
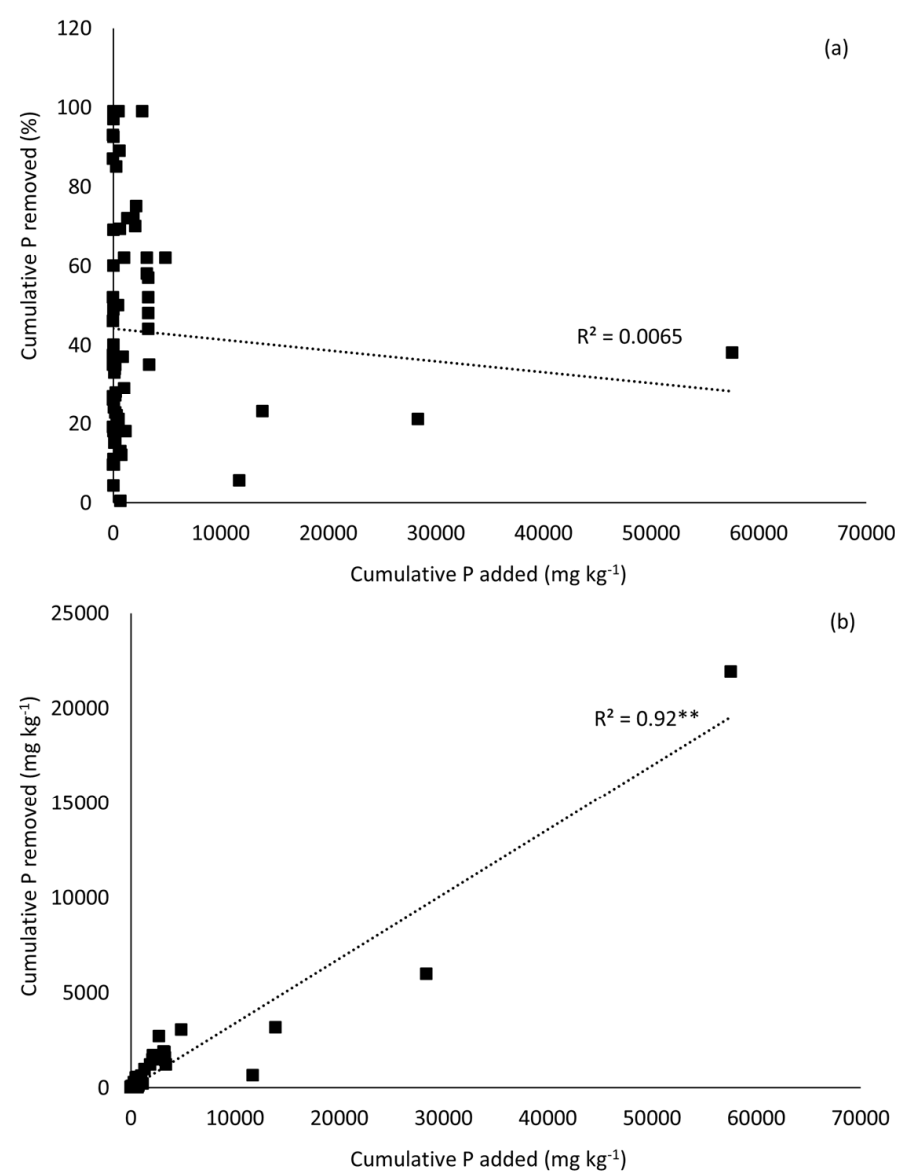

Figure 2. All cumulative $\mathrm{P}$ removal data from Table 1 expressed as: (a) a percentage; and (b) $\mathrm{mg} P$ removed $\mathrm{kg}^{-1} \mathrm{P}$ sorption material (PSM), plotted as a function of cumulative $\mathrm{P}$ loading.

Because of the impact of P loading, RT, and inflow $\mathrm{P}$ concentration on P removal, it is very difficult to make comparisons between studies and PSMs. However, plotting cumulative P removal—as $\mathrm{mg}$ $\mathrm{P} \mathrm{kg}^{-1} \mathrm{PSM}$ - as a function of cumulative $\mathrm{P}$ added illustrates the overall $\mathrm{P}$ removal efficiency if the $\mathrm{y}$-intercept is set to zero. In this manner, a slope of 1 is equal to $100 \%$ cumulative $P$ removal efficiency. Figure $2 \mathrm{~b}$ presents all the data in Table 1 as cumulative $\mathrm{P}$ added vs. cumulative $\mathrm{P}$ removed, with both values as $\mathrm{mg} \mathrm{kg}^{-1}$. The overall $\mathrm{P}$ removal efficiency for this relationship among all evaluated structures is 0.33 , i.e., $33 \%$ cumulative $P$ removal. This value represents the average for all the studies 
and should not be used as an assumption for any $P$ removal structure. Instead, Figure $2 b$ illustrates the greater utility of presenting $P$ removal data as cumulative $P$ removed in units of mass of $P$ per unit mass of PSM, along with the associated P loading value. Simply put, cumulative P removed per mass of PSM increases with greater P loading.

We can further refine this analysis by separating the data into general categories to reduce the confounding factors of inflow $\mathrm{P}$ concentration and RT. As previously discussed for materials that are sensitive to RT, an increase in RT will increase P removal. In addition, scenarios with higher inflow P concentrations tend to be more thermodynamically favorable for $\mathrm{P}$ removal, as discussed earlier. This was the guiding principle in organizing Table 1 and Figures 3 and 4 .
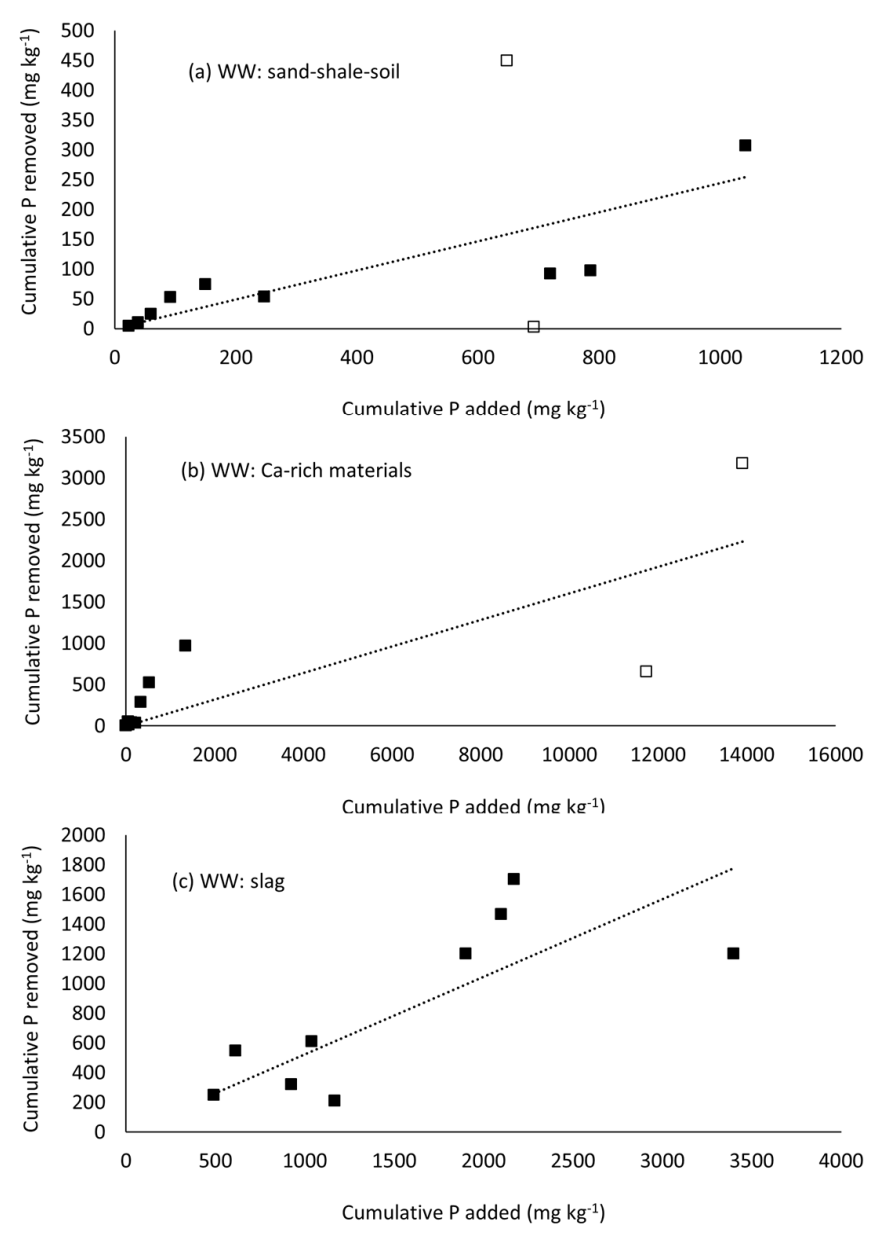

Figure 3. Cumulative $\mathrm{P}$ removed for studies with high dissolved $\mathrm{P}$ inflow concentrations and long retention time (RT), expressed as a function of cumulative P loading for the data listed in Table 1. All studies shown are for wastewater (WW) treatment with different P sorption materials (PSMs): (a) sand, shale, or soil; (b) Ca-rich materials not including steel slag; and (c) steel slag. Statistics are listed in Table 2. Open squares indicate highly influential points described in Table 2.

In the wastewater group, which was separated from non-point source drainage water, one exception was made for structures that treated wastewater with Fe-rich materials (Table 1). These structures were placed in their own category because they generally had inflow $\mathrm{P}$ concentrations and RTs similar to non-point drainage structures. Excluding the structures that contained Fe-rich PSMs, the average inflow $\mathrm{P}$ concentration for structures that treated wastewater was $9.4 \mathrm{mg} \mathrm{L}^{-1}$, with an average RT of $92 \mathrm{~h}$. Separately, the Fe-rich PSMs structures that treated wastewater exhibited an average inflow P concentration and RT of $1.25 \mathrm{mg} \mathrm{L}^{-1}$ and $24 \mathrm{~h}$, respectively-although this was highly skewed from a single study so that the median was $0.15 \mathrm{mg} \mathrm{L}^{-1}$ and $0.03 \mathrm{~h}$. The reason for the low concentrations of $\mathrm{P}$ 
in wastewater in this group was because the studies were mostly conducted on trout farm wastewater. Including that group with the non-point drainage water resulted in an average inflow $\mathrm{P}$ concentration and RT of $1.36 \mathrm{mg} \mathrm{L}^{-1}$ and $13 \mathrm{~h}$, respectively (median of $0.54 \mathrm{mg} \mathrm{L}^{-1}$ and $0.17 \mathrm{~h}$ ). Excluding that group from the non-point drainage water slightly changed those values to an average inflow $\mathrm{P}$ concentration of $1.39 \mathrm{mg} \mathrm{L}^{-1}$ and RT of $10.2 \mathrm{~h}$, respectively (median of $0.58 \mathrm{mg} \mathrm{L}^{-1}$ and $0.22 \mathrm{~h}$ ).
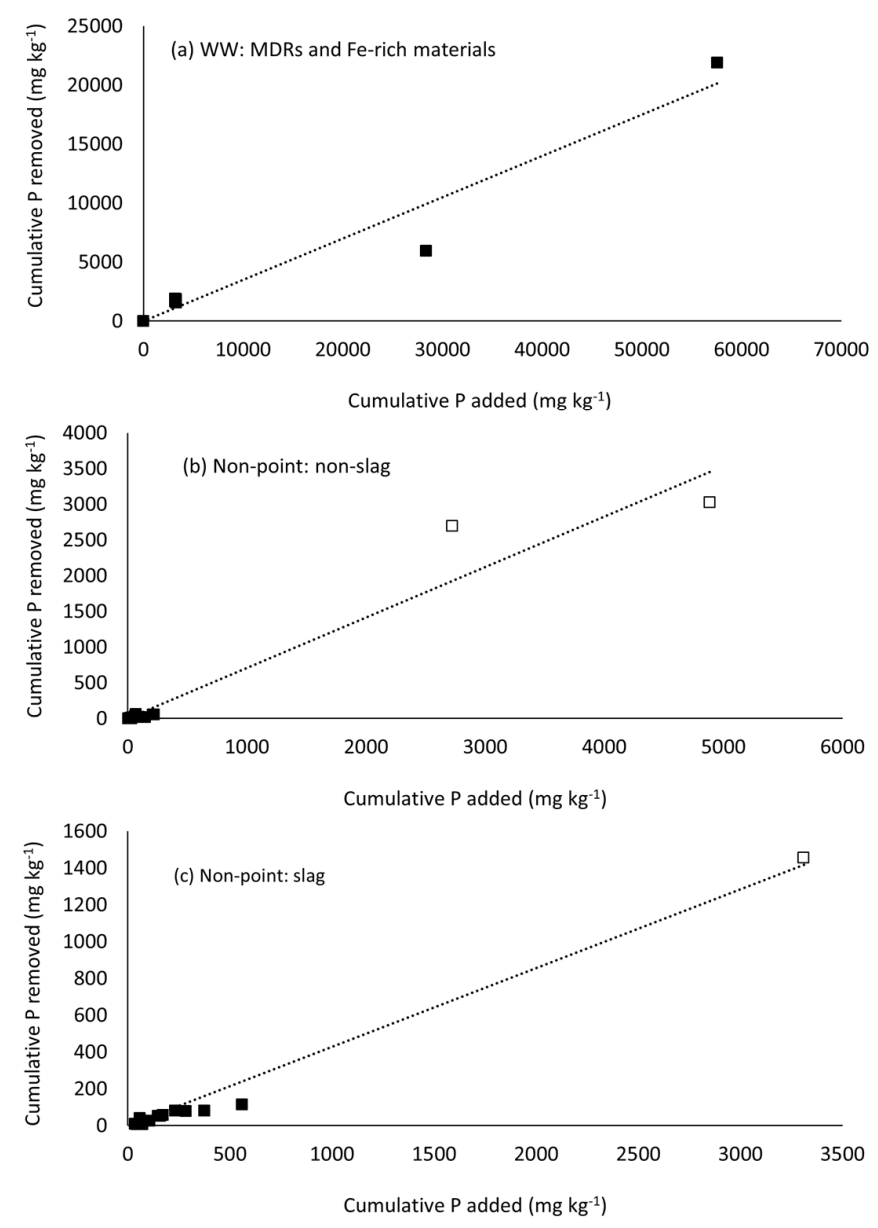

Figure 4. Cumulative P removed for studies with low dissolved P inflow concentrations and short retention time (RT), expressed as a function of cumulative P loading for the data listed in Table 1: (a) wastewater (WW) treated with mine drainage residuals (MDRs) and Fe-rich materials; (b) non-point source drainage water treated with non-slag materials; and (c) non-point drainage water treated with slag. Statistics are listed in Table 2. "Non-point" refers to non-point source drainage water. Open squares indicate highly influential points described in Table 2.

The PSM separation within the categories of wastewater and non-point drainage water serves to organize the data in a fashion that allows for a crude comparison between P removal structures and PSMs, while indirectly taking into account the inflow P concentration and RT. Thus, the relationship between cumulative $\mathrm{P}$ added and cumulative $\mathrm{P}$ removed (y-intercept set to 0 ), in $\mathrm{mg} \mathrm{P} \mathrm{kg}^{-1} \mathrm{PSM}$, are shown for each category in Figures 3 and 4 . The cumulative P removal efficiency (i.e., slope) for each category is shown in Table 2. Table 2 also lists the P removal efficiency when the highly influential data points were removed; those points are indicated as the non-filled markers in Figures 3 and 4. 
Table 2. Overall phosphorus $(\mathrm{P})$ removal efficiency for each category of $\mathrm{P}$ removal structures shown in Table 1 and Figures 3 and 4. Overall removal efficiency is the slope (times 100) of the relationship between cumulative $P$ added and cumulative P removed when the Y-intercept is set to zero. Efficiency is listed for each P-structure category for all data and with removal of highly influential data points, which are indicated as non-filled markers in Figures 3 and 4.

\begin{tabular}{ccc}
\hline Category of P Removal Structure & $\begin{array}{c}\text { Cumulative P Removal } \\
\text { Efficiency (\%): All Data }\end{array}$ & $\begin{array}{c}\text { Cumulative P Removal Efficiency (\%): } \\
\text { Highly Influential Points Removed }\end{array}$ \\
\hline Waste water: sand-shale-soil & $24^{\mathrm{NS}}$ & $21^{* *}$ \\
Waste water: Ca-rich materials & $16^{* *}$ & $\mathrm{74}$ \\
Waste water: slag & $52^{* *}$ & $\mathrm{NA}$ \\
Waste water: MDRs and Fe-rich materials & $35^{* *}$ & $29^{* *}$ \\
Non-point: non-slag & $71^{* *}$ & $25^{* *}$ \\
Non-point: slag & $43^{* *}$ & \\
\hline
\end{tabular}

$*$ and ${ }^{* *}$ indicate $p$ values $<0.05$ and 0.01 , respectively, for the relationships between cumulative $\mathrm{P}$ added and removed; NA: not applicable; NS: not significant.

Figure 3 shows the studies that generally had a long RT and high inflow P concentrations. Sand, shale, and soil were placed in the same group here because of the lack of potency of these materials to serve as PSMs (Figure 3a). Regardless, this group of P removal structures still had an overall efficiency of $24 \%$ P removal (Table 2). Keep in mind that the P removal was likely not solely from P sorption, but at least partly due to biological removal due to the extensive RT (average and median of 100 and $144 \mathrm{~h}$ ). The high inflow P concentrations (mean and median of 6.3 and $6.4 \mathrm{mg} \mathrm{L}^{-1}$ ) also help to promote biological P removal, although this is minimal in treatment wetlands [64]. While biological P removal may also be occurring to some degree in the other two groups shown in Figure 3 (Ca-rich and slag), it is likely to be negligible due to the higher $\mathrm{pH}$ of these PSMs, which often exceeds 9. Notice the greater cumulative P removal efficiency for the Ca-rich materials compared to the sand-shale-soil $(74 \%$ vs. $21 \%$ with highly influential points removed), even though the average RT is similar at $122 \mathrm{~h}$ (Table 2). The Ca-rich materials remove $P$ through Ca phosphate precipitation, a more efficient process when compared to sorption and biological removal by the sand-shale-soil materials. Calcium phosphate precipitation is also the main mechanism through which slag is able to remove $\mathrm{P}$, which explains the great similarity in cumulative $\mathrm{P}$ removal efficiency when comparing the wastewater slag and Ca-rich materials (Figure 3b,c) in Table 2. Still, the greater P removal efficiency for the studies in the Ca-rich category ( $74 \%$ vs. $52 \%$ for Ca-rich PSMs and slag, respectively) is likely due to the lesser average RT of the wastewater slag structures (122 vs. $42 \mathrm{~h}$ ). Consider that PSMs dominated in Ca content (and therefore Ca-phosphate precipitation mechanism) tend to be responsive to increased RT.

Figure 4 shows the categories of $\mathrm{P}$ removal structures that generally had low inflow $\mathrm{P}$ concentrations and short RTs. Because of these conditions, these categories have lower cumulative $\mathrm{P}$ removal efficiency in comparison to the wastewater $P$ removal structures constructed with Ca-rich PSMs and slag (Table 2). Within the categories shown in Figure 4, the higher value for cumulative P removal efficiency for the Fe-rich samples compared to the other two categories-excluding highly influential points-is expected; the reason being is the greater efficiency of the ligand exchange mechanism compared to Ca phosphate precipitation. Consider that only three of the studies in the non-slag category for non-point drainage were not Ca-rich materials (Table 1). In fact, among the non-slag category, the studies displaying the two highest cumulative P removal values were from Fe-coated sand and MDRs; note that the high percent cumulative P removal was not due to small inflow loading. This conclusion supports the common laboratory observation that Fe-rich PSMs will typically remove a greater mass of P per unit mass of PSM, for a given P loading compared to Ca-based PSMs such as slag and gypsum.

\section{Feasibility and Economics}

While no values can be provided with regard to economics in this paper, the cost and feasibility of the P removal structures in this review can be discussed qualitatively. Several variables will control 
the magnitude of cost and the overall feasibility of $\mathrm{P}$ removal structure construction for a given site, including input $\mathrm{P}$ load, $\mathrm{P}$ removal goal, and lifetime. Two of the most important variables are the mass of PSM required to meet the P removal goals and cost per unit mass of PSM. Obviously, the greater the mass of PSM required, the greater the cost and difficulty of constructing a structure. Since the mass of PSM required is partly dictated by the PSM efficiency, more efficient PSMs will result in smaller structures. Since PSMs are generally more efficient at greater inflow $\mathrm{P}$ concentrations, sites with higher $\mathrm{P}$ concentrations will require smaller structures. For a given $\mathrm{P}$ loading, wastewater is much more efficient to treat than non-point drainage, considering the longer RTs and higher inflow P. Regardless, a smaller required mass of PSM will translate to lower PSM transportation costs and area required to build the structure.

The cost of a structure is directly related to its area. Not only is the area of a PSM bed dictated by the mass of PSM, it is also partly a function of the hydraulic conductivity of the PSM and the maximum flow rate for the structure. Simply put, PSMs with low hydraulic conductivity must be used at shallow depths in order to meet required flow rates, thereby increasing area and cost. Similarly, PSMs that require a long RT and are used on sites that demand high flow rates must be implemented over a larger area in order to meet the long retention time. This is accomplished by increasing the total pore volume of media, thereby increasing PSM volume, mass, and therefore area of structure. Note that the hydraulic conductivity of a PSM is strongly dictated by its particle size distribution; achieving a long RT with PSMs possessing large hydraulic conductivity (e.g., sieved slag) and likewise obtaining sufficient flow rates through fine-textured materials (e.g., FGD gypsum) with small hydraulic conductivity can be a challenge in design of a P removal structure.

While mass of PSM and required area of structure are clearly major factors in cost and feasibility, the cost and availability of the PSM will also partly control cost. For example, while some materials may be excellent PSMs and are available at a low cost, if they are located at excessive distances then transportation costs could exceed the budget for a structure. On the other hand, some manufactured PSMs are highly efficient at P removal, therefore required in smaller amounts which will reduce transportation costs and size of the structure. However, such PSMs are often expensive per unit mass. Although it might seem intuitive to always utilize the least expensive PSM on a mass basis, a designer must consider all factors: PSM P removal efficiency, transportation costs, construction costs, cleanout and maintenance, and PSM cost. Depending on the cost and P removal efficiency of a PSM, a less efficient PSM requiring a larger structure, more frequent cleanout, and higher transportation costs may be more or less cost effective than a more expensive and efficient PSM. For example, steel slag can often be obtained for transportation costs only, while manufactured PSMs with much greater P removal efficiency will usually cost between 17 and 27 USD per kg PSM. While the use of slag will result in greater transportation and construction costs than the manufactured PSM, the total cost of the structure may still be less due to the high cost of manufactured PSMs.

Almost every P removal structure included in this review operated passively, not requiring any pumps or energy consumption during operation. Passive movement of water through the P removal structure and subsequent outflow considerably reduces energy use and cost. For lower volume/high $P$ concentration sources such as wastewater, active filtration through the use of pumps may be justified; this is not the case for urban stormwater and most cases of agriculture drainage water.

Regarding maintenance, the most important considerations are potential clogging and the regular replacement of the PSMs after they have reached their useful lifetime. First, clogging can be avoided by use of more conventional BMPs that prevent erosion and sediment transport. For example, buffer strips can filter runoff before entering a P removal structure. Materials that consist of small particle size are more likely to experience a reduction in hydraulic conductivity with excessive sediment loading compared to course-textured PSMs. Since proper design of a P removal structure takes into account lifetime of the PSM, the cost of PSM cleanout and replacement can also be determined. Simply put, structures designed and constructed for shorter lifetimes-i.e., reduced mass of PSM, smaller 
structure-will require more frequent replacement of PSMs, although the cost per cleanout will be potentially less compared to structures designed for longer lifetimes, given the same PSM and site.

With respect to feasibility of $\mathrm{P}$ removal structures, other considerations include $\mathrm{pH}$ and competing anions in the influent water, and potential formation of anoxic conditions. For non-point source water, the $\mathrm{pH}$ of the treated water is dictated by the $\mathrm{pH}$ of the $\mathrm{PSM}$, and thus the $\mathrm{pH}$ of influent water is not a major concern. However, some wastewaters are highly $\mathrm{pH}$ buffered at a high $\mathrm{pH}$ level and may present a concern when using a Fe/Al-based PSM for treatment since such materials operate most efficiently at low to neutral $\mathrm{pH}$. Some organic anions such as citrate and oxalate can compete with phosphate for adsorption onto $\mathrm{Fe}$ and $\mathrm{Al}$ minerals; again, this is a greater concern for treatment of wastewater than for non-point source water. Regarding redox conditions, it is critical that $\mathrm{P}$ removal structures that utilize Fe or sulfur-rich PSMs such as mine drainage residuals be designed to drain free in between flow events [11]. If such materials are allowed to develop anoxic conditions, Fe solubility will increase and can release previously sorbed P. Depending on $\mathrm{pH}$, sulfur may be converted into hydrogen sulfide gas.

\section{Summary and Conclusions}

Phosphorus removal structures are diverse in styles and PSM composition, but all of them must possess the four main requirements of high inflow $\mathrm{P}$ concentration $\left(>0.2 \mathrm{mg} \mathrm{L}^{-1}\right)$, placement in a hydrologically active location, flow at an acceptable rate through the contained PSM, and the ability to replace or rejuvenate the PSM after it becomes spent. Evaluating a P removal structure or PSM performance based on percent cumulative or discrete $\mathrm{P}$ removal is an extremely limited statistic when not presented with the associated values of inflow cumulative $P$ loading in units of mass of $P$ per unit PSM mass. Ideally, performance should be presented as cumulative $P$ removal (mass of P per mass of PSM) as a function of cumulative P loading, along with some indication of the inflow P concentration and RT.

A great diversity of $P$ removal performance was reported in this review, and comparison between studies, even when accounting for cumulative P loading, was difficult due to the confounding factors of inflow P concentration and RT. However, in an attempt to somewhat isolate these factors, it was shown that studies involving the treatment of wastewater were more efficient in P removal compared to non-point drainage water due to the greater inflow $\mathrm{P}$ concentrations and designs that allowed for a longer RT compared to the non-point drainage structures. Nevertheless, for wastewater treatment, the use of materials such as shale, soil, and sand, were generally less effective due to a lower P sorption capacity (overall 21\% cumulative removal efficiency). For Ca-rich PSMs, including slag, increased RT allowed for greater P removal. Overall cumulative removal efficiency for slag treating wastewater was $52 \%$. For low inflow P concentrations and short RTs, Fe-based PSMs that removed dissolved P via ligand exchange mechanisms were more efficient than the Ca-rich PSMs, including slag. This was especially evident among the low input P concentration and low RT structures where the Fe-based materials had an overall higher cumulative removal efficiency of $35 \%$ compared to the non-slag and slag materials used in non-point drainage structures (29\% and $25 \%$, respectively). For optimum use of Ca-rich PSMs, the RT should be maximized as much as possible. In fact, values of RT from $10 \mathrm{~min}$ to several hours will greatly enhance P removal. However, long RTs translate to a greater PSM mass and area when additionally designing a structure to handle high flow rates, which can greatly increase cost of construction. If design of a structure to achieve a long RT and simultaneous high flow rate is not possible for a given site, then one might consider use of a Fe or Al-rich PSM that are generally not as sensitive to RT as Ca-rich materials. Overall, achieving a desired RT and flow rate is strongly influenced by PSM hydraulic conductivity, and therefore particle size distribution [11]. 
Because of the diversity among PSMs and P removal structures in terms of efficiency, cost of structure construction and longevity for a given $\mathrm{P}$ load and conditions will vary dramatically. In addition, due to this diversity, the specificities of a site will define the type and style of P removal structure and PSM to be used. Hence, a careful design process is required for ensuring optimal efficiency according to the site's unique conditions. Properly evaluating the performance of $\mathrm{P}$ removal structures allows for further advances in design and success of these remediation strategies. Future research in PSM regeneration-allowing PSMs to be re-used rather than replaced-will benefit the efficacy and economics of P removal structures, and therefore their widespread adoption. However, consider that regeneration of PSMs for the purpose of obtaining P fertilizer is generally not economically viable, except perhaps for wastewater treatment. Regarding non-point drainage water, the "paradox of dissolved P losses" [11], which is the great discrepancy between relatively small $\mathrm{P}$ loads in drainage water compared to much larger crop and plant P demands, the cost of stripping P from spent PSMs greatly outweighs the potential fertilizer benefit. However, this lack of cost-effectiveness is not true if the purpose of stripping/regenerating spent PSMs is for re-using the PSMs again.

Author Contributions: Isis Chagas, Chad J. Penn, Aleksandar Klimeski, and Gry Lyngsie compiled and reviewed relevant studies for this manuscript, and performed a critical analysis of each paper to glean the necessary data for inclusion. They also contributed to conceiving the techniques for normalizing the data and helped to write the manuscript. Chad Penn created the figures and tables and wrote the first draft of the manuscript.

Conflicts of Interest: The authors declare no conflict of interest.

\section{References}

1. Scavia, D.; Allan, J.D.; Arend, K.K.; Bartell, S.; Beletsky, D.; Bosch, N.S.; Brandt, S.B.; Briland, R.D.; Daloğlu, I.; DePinto, J.V.; et al. Assessing and addressing the re-eutrophication of Lake Erie: Central basin hypoxia. J. Gt. Lakes Res. 2014, 40, 226-246. [CrossRef]

2. Lehmann, J.; Lan, Z.; Hyland, C.; Sato, S.; Solomon, D.; Ketterings, Q.M. Long-Term dynamics of phosphorus forms and retention in manure-amended soils. Environ. Sci. Technol. 2005, 39, 6672-6680. [CrossRef] [PubMed]

3. Vadas, P.A.; Kleinman, P.J.A.; Sharpley, A.N.; Turner, B.L. Relating soil phosphorus to dissolved phosphorus in runoff: A single extraction coefficient for water quality modeling. J. Environ. Qual. 2005, 34, 572-580. [CrossRef] [PubMed]

4. Williams, M.R.; King, K.W.; Fausey, N.R. Drainage water management effects on tile discharge and water quality. Agric. Water Manag. 2015, 148, 43-51. [CrossRef]

5. $\quad$ Ross, J.A.; Herbert, M.E.; Sowa, S.P.; Frankenberger, J.R.; King, K.W.; Christopher, S.F.; Tank, J.L.; Arnold, J.G.; White, M.J.; Yen, H. A synthesis and comparative evaluation of factors influencing the effectiveness of drainage water management. Agric. Water Manag. 2016, 178, 366-376, [CrossRef]

6. Sharpley, A.N.; Chapra, S.C.; Wedepohl, R.; Sims, J.T.; Daniel, T.C.; Reddy, K.R. Managing agricultural phosphorus for protection of surface waters: Issues and options. J. Environ. Qual. 1994, 23, 437-451. [CrossRef]

7. Withers, P.J.; Davidson, I.A.; Foy, R.H. Prospects for controlling nonpoint phosphorus loss to water: A UK perspective. J. Environ. Qual. 2000, 29, 167-175. [CrossRef]

8. Organization for Economic Cooperation and Development (OECD). Water quality: Nitrates, phosphorus and pesticides. In OECD Compend. of Agri-Environ. Indic; OECD Publishing: Paris, France, 2013. [CrossRef]

9. Fiorellino, N.; Kratochvil, R.; Coale, F. Long-term agronomic drawdown of soil phosphorus in Mid-Atlantic coastal plain soils. Agron. J. 2017, 109, 1-7. [CrossRef]

10. Gotcher, M.J.; Zhang, H.; Schroder, J.L.; Payton, M.E. Phytoremediation of soil phosphorus with crabgrass. Agron. J. 2014, 106, 528-536. [CrossRef]

11. Penn, C.J.; Bowen, J.M. Design and Construction of Phosphorus Removal Structures for Improving Water Quality, 1st ed.; Springer International Publishing: Gewerbestrasse, Switzerland, 2018; p. 228. ISBN 978-3-319-58657-1.

12. Penn, C.J.; McGrath, J.M.; Rounds, E.; Fox, G.; Heeren, D. Trapping phosphorus in runoff with a phosphorus removal structure. J. Environ. Qual. 2012, 41, 672-679. [CrossRef] [PubMed] 
13. Penn, C.J.; McGrath, J.M.; Bowen, J.; Wilson, S. Phosphorus removal structures: A management option for legacy phosphorus. J. Soil Water Conserv. 2014, 69, 51A-56A. [CrossRef]

14. Shilton, A.; Elmetri, I.; Drizo, A.; Pratt, S.; Haverkamp, R.G.; Bilby, S.C. Phosphorus removal by an 'active' slag filter-A decade of full scale experience. Water Res. 2006, 40, 113-118. [CrossRef] [PubMed]

15. Dobbie, K.E.; Heal, K.V.; Aumônier, J.; Smith, K.A.; Johnston, A.; Younger, P.L. Evaluation of iron ochre from mine drainage treatment for removal of phosphorus from wastewater. Chemosphere 2009, 75, 795-800. [CrossRef] [PubMed]

16. Ballantine, D.J.; Tanner, C.C. Substrate and filter materials to enhance phosphorus removal in constructed wetlands treating diffuse farm runoff: A review. N. Z. J. Agric. Res. 2010, 53, 71-95. [CrossRef]

17. Arias, C.A.; Brix, H.; Johansen, N.-H. Phosphorus removal from municipal wastewater in an experimental two-stage vertical flow constructed wetland system equipped with a calcite filter. Water Sci. Technol. 2003, 48, 51-58. [PubMed]

18. Weber, D.; Drizo, A.; Twowig, E.; Bird, S.; Ross, D.A. Upgrading constructed wetlands phosphorus reduction from a dairy effluent using electric arc furnace steel slag filters. Water Sci. Technol. 2007, 56, 135-143. [CrossRef] [PubMed]

19. Groenenberg, J.E.; Chardon, W.J.; Koopmans, G.F. Reducing phosphorus loading of surface water using iron-coated sand. J. Environ. Qual. 2013, 42, 250-259. [CrossRef] [PubMed]

20. McDowell, R.W.; Sharpley, A.N.; Bourke, W. Treatment of drainage water with industrial by-products to prevent phosphorus loss from tile-drained land. J. Environ. Qual. 2008, 37, 1575-1582. [CrossRef] [PubMed]

21. Penn, C.; Bowen, J.; McGrath, J.; Nairn, R.; Fox, G.; Brown, G.; Wilson, S.; Gill, C. Evaluation of a universal flow-through model for predicting and designing phosphorus removal structures. Chemosphere 2016, 151, 345-355. [CrossRef] [PubMed]

22. Klimeski, A.; Uusitalo, R.; Turtola, E. Variations in phosphorus retention by a solid material while scaling up its application. Environ. Technol. Innov. 2015, 4, 285-298. [CrossRef]

23. Kirkkala, T.; Ventelä, A.-M.; Tarvainen, M. Long-term field-scale experiment on using lime filters in an agricultural catchment. J. Environ. Qual. 2012, 41, 410-419. [CrossRef] [PubMed]

24. Liu, J.; Davis, A.P. Phosphorus speciation and treatment using enhanced phosphorus removal bioretention. Environ. Sci. Technol. 2014, 48, 607-614. [CrossRef] [PubMed]

25. Chavez, R.A.; Brown, G.O.; Coffman, R.R.; Storm, D.E. Design, construction, and lessons learned from Oklahoma bioretention cell demonstration project. Appl. Eng. Agric. 2015, 31, 63-71. [CrossRef]

26. Feyereisen, G.W.; Francesconi, W.; Smith, D.R.; Papiernik, S.K.; Krueger, E.S.; Wente, C.D. Effect of replacing surface inlets with blind or gravel inlets on sediment and phosphorus subsurface drainage losses. J. Environ. Qual. 2015, 44. [CrossRef] [PubMed]

27. Lyngsie, G.; Penn, C.J.; Hansen, H.C.B.; Borggaard, O.K. Phosphate sorption by three potential filter materials as assessed by isothermal titration calorimetry. J. Environ. Manag. 2014, 143, 26-33. [CrossRef] [PubMed]

28. Karczmarczyk, A.; Bus, A. Testing of reactive materials for phosphorus removal from water and wastewater-Comparative study. Ann. Warsaw Univ. Life Sci. SGGQ Land Reclam. 2014, 46, 57-67. [CrossRef]

29. Eveborn, D.; Gustafsson, J.P.; Hesterberg, D.; Hillier, S. XANES speciation of P in environmental samples: An assessment of filter media for on-Site wastewater treatment. Environ. Sci. Technol. 2009, 43, 6515-6521. [CrossRef] [PubMed]

30. Baker, M.J.; Blowes, D.W.; Ptacek, C.J. Laboratory development of permeable reactive mixtures for the removal of phosphorus from onsite wastewater disposal systems. Environ. Sci. Technol. 1998, 32, 2308-2316. [CrossRef]

31. Johansson, L. Industrial by-products and natural substrata as phosphorus sorbents. Environ. Technol. 1999, 20, 309-316. [CrossRef]

32. Vohla, C.; Kõiv, M.; Bavor, H.J.; Chazarenc, F.; Mander, Ü. Filter materials for phosphorus removal from wastewater in treatment wetlands: A review. Ecol. Eng. 2011, 37, 70-89. [CrossRef]

33. Hedström, A. Reactive filter systems for small scale wastewater treatment: A literature review. Vatten 2006, $62,253-263$.

34. Klimeski, A.; Chardon, W.J.; Turtola, E.; Uusitalo, R. Potential and limitations of phosphate retention media in water protection: A process-based review of laboratory and field-scale tests. Agric. Food Sci. 2012, 21, 206-223. 
35. Westholm, L.J. Substrates for phosphorus removal-Potential benefits for on-site wastewater treatment? Water Res. 2006, 40, 23-36. [CrossRef] [PubMed]

36. Stoner, D.; Penn, C.; McGrath, J.; Warren, J. Phosphorus removal with by-products in a flow-through setting. J. Environ. Qual. 2012, 41, 654-663. [CrossRef] [PubMed]

37. Penn, C.J.; McGrath, J.M. Predicting phosphorus sorption onto steel slag using a flow-through approach with application to a pilot scale system. J. Water Resour. Prot. 2011, 3, 235-244. [CrossRef]

38. Hill, C.M.; Duxbury, J.; Geohring, L.; Peck, T. Designing constructed wetlands to remove phosphorus from barnyard runoff: A comparison of four alternative substrates. J. Environ. Sci. Health 2000, A35, 1357-1375. [CrossRef]

39. Pant, H.K.; Reddy, K.R.; Lemon, E. Phosphorus retention capacity of root bed media of sub-surface flow constructed wetlands. Ecol. Eng. 2001, 17, 345-355. [CrossRef]

40. Forbes, M.G.; Dickson, K.R.; Golden, T.D.; Hudak, P.; Doyle, R.D. Dissolved phosphorus retention of light-weight expanded shale and masonry sands used in subsurface flow treatment wetlands. Environ. Sci. Technol. 2004, 38, 892-898. [CrossRef] [PubMed]

41. Kholoma, E.; Renman, G.; Renman, A. Phosphorus removal from wastewater by field-scale fortified filter beds during a one-year study. Environ. Technol. 2016, 37, 2953-2963. [CrossRef] [PubMed]

42. Szögi, A.A.; Humenik, F.J.; Rice, J.M.; Hunt, P.G. Swine wastewater treatment by media filtration. J. Environ. Sci. Health 1997, B32, 831-843. [CrossRef] [PubMed]

43. Gray, S.; Kinross, J.; Read, P.; Marland, A. The nutrient assimilative capacity of maerl as a substrate in constructed wetland systems for waste treatment. Water Res. 2000, 34, 2183-2190. [CrossRef]

44. Comeau, Y.; Brisson, J.; Réville, J.-P.; Forget, C.; Drizo, A. Phosphorus removal from trout farm effluents by constructed wetlands. Water Sci. Technol. 2001, 44, 55-60. [PubMed]

45. Vohla, C.; Põldvere, E.; Noorvee, A.; Kuusemets, V.; Mander, Ü. Alternative filter media for phosphorous removal in a horizontal subsurface flow constructed wetland. J. Environ. Sci. Health 2005, A40, 1251-1264. [CrossRef]

46. Søvik, A.K.; Kløve, B. Phosphorus retention processes in shell sand filter systems treating municipal wastewater. Ecol. Eng. 2005, 25, 168-182. [CrossRef]

47. Ádám, K.; Søvik, A.K.; Krogstad, T. Sorption of phosphorus to Filtralite-PTM-The effect of different scales. Water Res. 2006, 40, 1143-1154. [CrossRef] [PubMed]

48. Karczmarczyk, A.; Renman, G. Phosphorus Accumulation Pattern in a Subsurface Constructed Wetland Treating Residential Wastewater. Water 2011, 3, 146-156. [CrossRef]

49. Shilton, A.; Pratt, S.; Drizo, A.; Mahmood, B.; Banker, S.; Billings, L.; Glenny, S.; Luo, D. 'Active' filters for upgrading phosphorus removal from pond systems. Water Sci. Technol. 2005, 51, 111-116. [PubMed]

50. Korkusuz, E.A.; Beklioğlu, M.; Demirer, G.N. Use of blast furnace granulated slag as a substrate in vertical flow reed beds: Field application. Bioresour. Technol. 2007, 98, 2089-2101. [CrossRef] [PubMed]

51. Bird, S.; Drizo, A. EAF steel slag filters for phosphorus removal from milk parlor effluent: The effects of solids loading, alternate feeding regimes and in-series design. Water 2010, 2, 484-499. [CrossRef]

52. Renman, A.; Renman, G. Long-term phosphate removal by the calcium-silicate material Polonite in wastewater filtration systems. Chemosphere 2010, 79, 659-664. [CrossRef] [PubMed]

53. Barca, C.; Troesch, S.; Meyer, D.; Drissen, P.; Andrès, Y.; Chazarenc, F. Steel Slag Filters to Upgrade Phosphorus Removal in Constructed Wetlands: Two Years of Field Experiments. Environ. Sci. Technol. 2013, 47, 549-556. [CrossRef] [PubMed]

54. Wood, R.B.; McAtamney, C.F. Constructed wetlands for waste water treatment: The use of laterite in the bed medium in phosphorus and heavy metal removal. Hydrobiologia 1996, 340, 323-331. [CrossRef]

55. Sibrell, P.L.; Kehler, T. Phosphorus removal from aquaculture effluents at the Northeast Fishery Center in Lamar, Pennsylvania using iron oxide sorption media. Aquac. Eng. 2016, 72-73, 45-52. [CrossRef]

56. Penn, C.J.; Bryant, R.B.; Kleinman, P.J.A.; Allen, A.L. Removing dissolved phosphorus from drainage ditch water with phosphorus sorbing materials. J. Soil Water Conserv. 2007, 62, 269-276.

57. Faucette, B.; Cardoso, F.; Mulbry, W.; Millner, P. Performance of compost filtration practice for green infrastructure stormwater applications. Water Environ. Res. 2013, 85, 806-814. [CrossRef] [PubMed]

58. Bryant, R.B.; Buda, A.R.; Kleinman, J.A.; Church, C.D.; Saporito, L.S.; Folmar, G.J.; Bose, S.; Allen, A.L. Using flue gas desulfurization gypsum to remove dissolved phosphorus from agricultural drainage waters. J. Environ. Qual. 2012, 41, 664-671. [CrossRef] [PubMed] 
59. McDowell, R.W.; Hawke, M.; McIntosh, J.J. Assessment of a technique to remove phosphorus from streamflow. N. Z. J. Agric. Res. 2007, 50, 503-510. [CrossRef]

60. Agrawal, S.G.; King, K.W.; Moore, J.F.; Levison, P.; McDonald, J. Use of industrial byproducts to filter phosphorus and pesticides in golf green drainage water. J. Environ. Qual. 2011, 40, 1273-1280. [CrossRef] [PubMed]

61. Wang, Z.; Bell, G.E.; Penn, C.J.; Moss, J.Q.; Payton, M.E. Phosphorus reduction in turfgrass runoff using a steel slag trench filter system. J. Soil Water Conserv. 2015, 54, 1859-1867. [CrossRef]

62. Lyngsie, G.; Penn, C.J.; Pedersen, H.L.; Borggaard, O.K.; Hansen, H.C. Modelling of phosphate retention by Ca- and Fe-rich filter materials under flow-through conditions. Ecol. Eng. 2015, 75, 93-102. [CrossRef]

63. Klimeski, A.; Uusitalo, R.; Turtola, E. Screening of Ca- and Fe-rich materials for their applicability as phosphate-retaining filters. Ecol. Eng. 2014, 68, 143-154. [CrossRef]

64. Vymazal, J. Removal of nutrients in various types of constructed wetlands. Sci. Total Environ. 2007, 380, 48-65. [CrossRef] [PubMed]

(C) 2017 by the authors. Licensee MDPI, Basel, Switzerland. This article is an open access article distributed under the terms and conditions of the Creative Commons Attribution (CC BY) license (http://creativecommons.org/licenses/by/4.0/). 